\title{
Risk Factors That Leading to Cost and Time Overrun in Mega Construction Projects in Malaysia
}

\author{
Ammar Ali
}

Limkokwing University of Creative Technology, Cyberjaya, Selangor, Malaysia

This journal is licensed under a Creative Commons Attribution-NonCommercial 4.0 International License (CC-BY-NC). Articles can be read and shared for noncommercial purposes under the following conditions:

- BY: Attribution must be given to the original source (Attribution)

- NC: Works may not be used for commercial purposes (Noncommercial)

This license lets others remix, tweak, and build upon your work non-commercially, and although their new works must also acknowledge you and be non-commercial, they don't have to license their derivative works on the same terms. License Deed Link: http://creativecommons.org/licenses/by-nc/4.0/ Legal Code Link: http://creativecommons.org/licenses/by-nc/4.0/legalcode $A B C$ Research Alert uses the CC BY-NC to protect the author's work from misuse.

\section{Abstract}

The construction industry is truly the engine of national economy through which the total of physical development is achieved. The construction industry is a vital element of the economy and has a significant effect on the efficiency and productivity of other industry sectors. One cannot think of widespread investment in manufacturing, agriculture, or service sectors unless the construction results of infrastructure facilities are in place. In some of the developing countries, the growth rate of construction activity outstrips that of population and of GDP (Chitkara, 2004).

Cost, time, and quality are used to measure the project performance and success. Generally, the success of a project is defined by accomplishing it within specified cost, time and quality. However, the construction industry is full of projects that are completed with significant time and cost overruns (Amhel et al.,2010). According to Faridi et al. (2006) delays have an adverse impact on project success in terms of time, cost, quality and safety. The effects of construction delays are not confined to the construction industry only, but influence the overall economy of a country.

Construction industry is a very important industry in a country's development and it can increase or generate economic development of the country. A study showed that since seventies, the economic in Malaysia has undergone rapid growth. It found that construction industry constitutes an important element of Malaysian Economy However, majority of the construction are facing problem in achieving the completion of project within stipulated time and cost. In other words, time and cost overrun is a common issue that frequently happens in the construction project worldwide generally, time overruns happen when a task within a project is not completed by the time the project plan specifies. Meanwhile, cost overrun occurs when the expenses required to complete a project exceed the amount budgeted. Since seventies, the economics of Malaysia has undergone rapid growth. Construction industry constitutes an important element of Malaysian economy. It shows how important to control and manage the projects in good quality and efficiently. There are four fundamental constraints needed to be considered when managing the construction projects, which are scope, cost, time, and quality. In order to manage the projects successfully, it is necessary to consider whether the project is within those four constraints. Cost has its proven importance as the prime factor for project success.

Most of the significant factors affecting project costs are qualitative such as client priority on construction time, contractor's planning capability, procurement methods and market conditions including the level of construction activity (Elchaig et al, 2005). A project otherwise completed may not be regarded as a successful endeavor until and unless it satisfies the cost limitations applied to it. Cost 
is among the major considerations throughout the project management life cycle and can be regarded as one of the most important parameters of a project and the driving force of project success.

Despite its proven importance it is not uncommon to see a construction project failing to achieve its objectives within the specified cost. Cost overrun is a very frequent phenomenon and is almost associated with nearly all projects in the construction industry. This trend is more severe in developing countries where these overruns sometimes exceed $100 \%$ of the anticipated cost of the project.

The construction industry is large, complex, volatile, risky, and requires tremendous capital outlays and tight money. It provides a bigger challenge to maintain its scheduled time, budgetary cost, and appropriate quality (Shaikh et al., 2010). A major criticism facing the construction industry is the growing rate of cost overrun and delays in project delivery. Enshassi et al. $(2003,2008)$ explain that the increasing complexity of construction projects and the environment within which they are constructed place greater demands on construction managers to deliver projects on time, within budget and with high quality. On-time completion and conformity with assigned cost of every project are the most important factors in the success of project plans. However, completing construction projects on time and within budget has been a major problem (Flyvbjerg et al., 2003; Sanders and Eagles, 2001).

Construction delay and cost overrun occurs all over the world and many studies have been carried out to assess the causes of cost and time overruns in construction projects. For example, in Malaysia construction industry is highly dynamic sector and plays very important role in the development of country and hence in Malaysia, construction industry started a rapid growth since its independence. However, construction industry in Malaysia is facing chronic problems including poor performance of time and cost, construction waste, poor productivity and over dependent of foreign workers. Of these challenges, poor time and cost performance is considered as a critical issue. As reported by only $46.8 \%$ of public sector and $37.2 \%$ of private sector projects were found completed within the stipulated budget in Malaysia while only $20.5 \%$ of the public projects $33.35 \%$ of the private sector projects were completed within the time

\section{Keywords}

\section{Cost, Time, construction industry}

\section{INTRODUCTION}

The construction industry is truly the engine of national economy through which the total of physical development is achieved. The construction industry is a vital element of the economy and has a significant effect on the efficiency and productivity of other industry sectors. One cannot think of widespread investment in manufacturing, agriculture, or service sectors unless the construction results of infrastructure facilities are in place. In some of the developing countries, the growth rate of construction activity outstrips that of population and of GDP (Chitkara, 2004). Cost, time, and quality are used to measure the project performance and success. Generally, the success of a project is defined by accomplishing it within specified cost, time and quality.

However, the construction industry is full of projects that are completed with significant time and cost overruns (Amhel et al., 2010). According to Faridi et al. (2006) delays have an adverse impact on project success in terms of time, cost, quality and safety. The effects of construction delays are not confined to the construction industry only, but influence the

overall economy of a country. Cost estimation is particularly difficult in the construction industry, often leading to considerable cost overruns that are explained by large uncertainties and uniqueness of projects (Baker et al., 1995). One might expect that cost overruns have that same probability as completing the project below the cost estimate. However, observations clearly indicate an overrepresentation of cost overruns (Emhjellen, 2003).

The delivery of projects is performed using mainly traditional processes that have evolved from history and the industrial revolution, the failure of construction projects has been discussed by many authors, who have not agreed on a single method to measure success in a project. However, Morris and Hough (1987) suggested three different measures to recognize if a project is successful or not. Firstly, they mentioned the project functionality which means that the project should function technically and financially. Secondly, the authors proposed a second measure about the management of the project, which indicates if the project meets the 
budget and schedule targets. Finally, the project should be evaluated depending on the performance of the contractors which analyze if they provide services that benefit the project.

On the other hand, many other authors measure the success of a construction project assessing the time performance, cost performance and the final quality of the project (Chan, et al., 2004). Therefore, there is not a unique way of determining success in a project; however, cost performance is a critical issue to be considered in the success or failure of project. The failure of construction projects has been discussed by many authors, who have not agreed on a single method to measure success in a project. However, Morris and Hough (1987) suggested three different measures to recognize if a project is successful or not. Firstly, they mentioned the project functionality which means that the project should function technically and financially. Secondly, the authors proposed a second measure about the management of the project, which indicates if the project meets the budget and schedule targets. Finally, the project should be evaluated depending on the performance of the contractors which analyze if they provide services that benefit the project.

On the other hand, many other authors measure the success of a construction project assessing the time performance, cost performance and the final quality of the project (Chan, et al., 2004). Therefore, there is not a unique way of determining success in a project; however, cost performance is a critical issue to be considered in the success or failure of project. The delivery of the projects is performed using mainly traditional processes that have evolved from history and the industrial revolution, where speculation of professional organization was the key trend (Pakkala, 2002).

This means that architects, engineers, specialty contractors, and the industry have adopted a segmented rather than an in targeted type of process. In developed countries, the majority of projects have used the projects delivery method of design-bid-build (DBB) (Gould, 1997)., alternatively known as the tradition method, and typically consisting of discrete feasibility/preliminary design, full design, construction and operation.

\section{BACKGROUND OF THE RESEARCH}

The construction industry is truly the engine of national economy through which the total of physical development is achieved. The construction industry is a vital element of the economy and has a significant effect on the efficiency and productivity of other industry sectors. One cannot think of widespread investment in manufacturing, agriculture, or service sectors unless the construction results of infrastructure facilities are in place. In some of the developing countries, the growth rate of construction activity outstrips that of population and of GDP (Chitkara, 2004). Cost, time, and quality are used to measure the project performance and success. Generally, the success of a project is defined by accomplishing it within specified cost, time and quality. However, the construction industry is full of projects that are completed with significant time and cost overruns (Amhel et al.,2010). According to Faridi et al. (2006) delays have an adverse impact on project success in terms of time, cost, quality and safety. The effects of construction delays are not confined to the construction industry only, but influence the overall economy of a country. Cost estimation is particularly difficult in the construction industry, often leading to considerable cost overruns that are explained by large uncertainties and uniqueness of projects (Baker et al., 1995). One might expect that cost overruns have that same probability as completing the project below the cost estimate. However, observations clearly indicate an overrepresentation of cost overruns (Emhjellen, 2003).

The delivery of projects is performed using mainly traditional processes that have evolved from history and the industrial revolution, the failure of construction projects has been discussed by many authors, who have not agreed on a single method to measure success in a project. However, Morris and Hough (1987) suggested three different measures to recognize if a project is successful or not. Firstly, they mentioned the project functionality which means that the project should function technically and financially. Secondly, the authors proposed a second measure about the management of the project, which indicates if the project meets the budget and schedule targets. Finally, the project should be evaluated depending on the performance of the contractors which analyze if they provide services that benefit the project. On the other hand, many other authors measure the success of a construction project assessing the time performance, cost performance and the final quality of the project (Chan, et al., 2004). Therefore, there is not a unique way of determining success in a project; however, cost performance is a critical issue to be considered in the success or failure of project. 
The failure of construction projects has been discussed by many authors, who have not agreed on a single method to measure success in a project. However, Morris and Hough (1987) suggested three different measures to recognize if a project is successful or not. Firstly, they mentioned the project functionality which means that the project should function technically and financially. Secondly, the authors proposed a second measure about the management of the project, which indicates if the project meets the budget and schedule targets. Finally, the project should be evaluated depending on the performance of the contractors which analyze if they provide services that benefit the project. On the other hand, many other authors measure the success of a construction project assessing the time performance, cost performance and the final quality of the project (Chan, et al., 2004). Therefore, there is not a unique way of determining success in a project; however, cost performance is a critical issue to be considered in the success or failure of project.

The delivery of the projects is performed using mainly traditional processes that have evolved from history and the industrial revolution, where speculation of professional organization was the key trend (Pakkala, 2002). This means that architects, engineers, specialty contractors, and the industry have adopted a segmented rather than an in targeted type of process. In developed countries, the majority of projects have used the projects delivery method of design-bid-build (DBB) (Gould, 1997), alternatively known as the tradition method, and typically consisting of discrete feasibility/preliminary design, full design, construction and operation phases (Fig1.1).

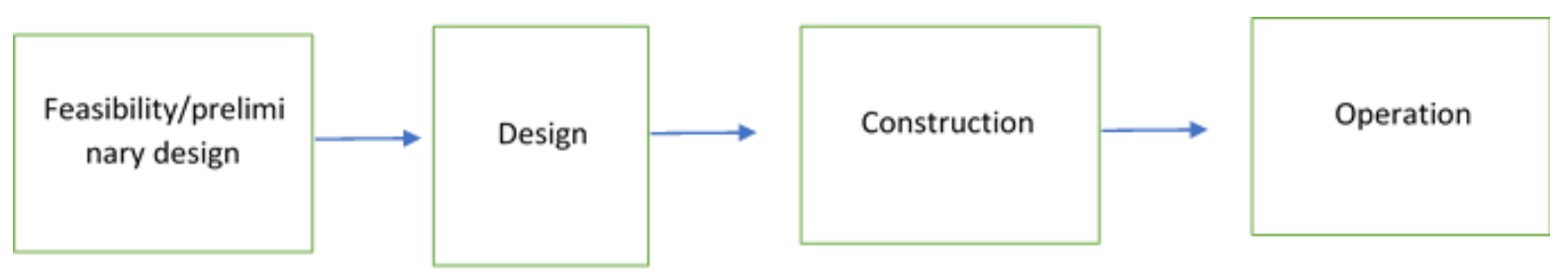

Figure 1.1: Traditional project development $\mathrm{t}$ phases

\section{DEFINITION OF THE PROBLEM}

Construction can be considered as a dynamic industry which is constantly facing uncertainties. These uncertainties and the many stakeholders in these kinds of projects, make the management of costs difficult which consequently causes cost overruns. Overruns are considered one of the most critical issues during the execution of construction projects (Chan, et al., 2004; Doloi, 2011). As mentioned by Van Der Westhuizen and Fitzgerald (2005), the presence of cost overruns can be a reason for project failure. However, this idea has been refuted by many authors who considered that project success depends on many other factors that should be assessed to conclude the success or failure of a project (Chan, et al., 2004). Moreover, there have been many studies that suggest that the success of a project depends on the presence of certain critical factors which can also change depending on the objective to be met (Iyer and Jha, 2005). In other words, some authors ascertained that there are some critical success factors that help to improve cost performance and prevent cost overruns. There have been many studies focused on Critical Success Factors [CSF's] that improve the overall performance of projects, such as the projects carried out by Baker, et al. (1983), Morris and Hough (1987), Belassi and Tukel (1996), among others. However, much of the existing research is not focused on the construction industry and more specifically on those critical success factors that influence the cost performance of construction projects. For this reason, an attempt will be made in this study to identify if certain CSFs can help to avoid cost overruns. Here some of the projects that faced cost overruns in Malaysia. 


\begin{tabular}{|c|c|c|c|c|c|}
\hline No. & Name of Project & $\begin{array}{c}\text { Project } \\
\text { Cost (Million) }\end{array}$ & $\begin{array}{l}\text { Project } \\
\text { Duration (days) }\end{array}$ & $\begin{array}{c}\text { Time } \\
\text { Overrun } \\
\text { (Days) }\end{array}$ & $\begin{array}{l}\text { \% Time } \\
\text { Overrun }\end{array}$ \\
\hline 1 & Construction of MRSM Kroh, & 33.6 & 504 & 335 & 66.47 \\
\hline 2 & $\begin{array}{l}\text { Construction of MRSM Kuala } \\
\text { Kangsar, Perak }\end{array}$ & 40.30 & 545 & 4 & 0.73 \\
\hline 3 & $\begin{array}{l}\text { Enlarge/Upgrade of IKM Lu- } \\
\text { mut, Perak. }\end{array}$ & 11.2 & 700 & 35 & 5.00 \\
\hline 4 & $\begin{array}{l}\text { Construction of KKTM Leng- } \\
\text { gong, Perak. }\end{array}$ & 113.3 & 791 & 21 & 2.65 \\
\hline 5 & $\begin{array}{l}\text { Fixing of Slipway Winh Sys- } \\
\text { tem, MIMET }\end{array}$ & 1,3 & 265 & 68 & 25.66 \\
\hline
\end{tabular}

Table 1: Projects that faced cost overruns in Malaysia

A success of any project can be assessed based on the performance of cost, time, quality and safety of the project (Atkinson, 1999; Memon et al., 2013). A project can be classified as successful if it is completed within the stipulated time and cost (Ejaz, Ali, \& Tahir, 2013). Besides that, the success of a project is also assessed on the ability in achieving the objectives of the project. However, it is rare for a construction project be completed within contractual time and cost where commonly a huge amount of time and cost overruns occur. Time and cost overruns are critical issues frequently faced by the construction project worldwide (Le-Hoai et al., 2008; Murray \& Seif, 2013; Sweis et al., 2013). This problem is considered as the recurring problem in construction project and gives negative impact to the projects (Sweis, 2013). Similarly, it is also a severe problem in Malaysian construction industry as reported by (Endut et al., 2009; Rahman et al., 2012). A study on 308 public and 51 private sectors construction projects found that only $20.5 \%$ of the public sector projects were completed within stipulated time and $46.8 \%$ of projects completed within the budget. On the other hand, only $33.35 \%$ and $37.2 \%$ of private sector projects were completed within the estimated time and cost respectively (Endut et al., 2009). Another study on MARA construction projects also found that $90 \%$ of the projects have experienced delay (Abdullah et al., 2011). More recently, the problem of time and cost overruns issue also happened in the construction of Kuala Lumpur International Airport 2 (known as KLIA2). The targeted opening was in September 2011 but was postponed until 3 May 2014. Its initial budget of RM1.6 billion has since ballooned to RM4 billion. These time and cost overruns were caused by various factors. For example: time and cost overruns in KLIA2 project occurred due to "frequent design change in construction" (Nie, 2014). These problems were caused by various factors that had affected the progress of works from beginning until the final stage of construction. Therefore, many studies have been conducted to identify the factors that cause time and cost overruns in Malaysian construction projects. Potty et al., (2011) conducted a case study to identify the risk of time and cost overrun factors for multiple Design and Build (D $\&$ B) projects in Malaysia. They pointed out that the major factors that led to time and cost overruns were; shortage and lack in quality materials and appropriate equipment in the local market, no material delivery schedule prepared by the contractor, delay in materials, drawing and proposal approvals by consultant and bad weather conditions. While, Rahman et al., (2013) studied on factors that had caused cost overrun in large construction projects and found three significant factors of cost overrun were fluctuation of prices of material.

\section{RESEARCH AIM}

To identify the major cost overrun factors in the construction sector in Malaysia and the effective remedial cost control measures, generate and recommend possible solutions. 


\section{OBJECTIVES OF THE STUDY}

Within the context of the study, the research project:

a) To identify the major causes of cost overruns and associated remedial measures for use in Malaysia construction.

b) To identify the common causes of cost overruns in public sector projects in Malaysia

c) Determine the plausible frequency of cost overruns among public sector and private sector projects in Malaysia.

d) Ascertain if the rate of cost overrun occurrence constitutes a performance problem in Malaysia construction project.

e) Formulate recommendations aimed at solving the current and future cost related challenges in Malaysia construction industry.

\section{SCOPE OF THE RESEARCH}

This study adopted quantitative approach in identifying and assessing the significant factors causing overrun. The data samples are collected through questionnaire survey amongst the clients, consultants and contractors involved in construction industry. Contractors were selected from "list of approved contractors" in Construction Industry Development Board (CIDB) Malaysia

The research will be focused on the following matter:

i. This research was comprised in Malaysia including Johor and Sabah region.

ii. The group of respondents for this research involves client, consultant and contractor companies that registered with Construction Industrial Development Board (CIDB).

\section{References}

Blair, J., Czaja, R. F., \& Blair, E. A. (2013). Designing surveys: A guide to decisions and procedures: Sage Publications.

Bogdan, R., \& Taylor, S. J. (1975). Introduction to qualitative methods: A phenomenological approach to the social sciences: New York: Wiley.

Bryman, A. (2006). Integrating quantitative and qualitative research: how is it done? Qualitative research, 6(1), 97-113.

Buckingham, A., \& Saunders, P. (2004). The survey methods workbook: From design to analysis: Polity Pr.

Chandy, R. K., Tellis, G. J., MacInnis, D. J., \& Thaivanich, P. (2001). What to say when: Advertising appeals in evolving markets. Journal of marketing Research, 38(4), 399-414.

Child, D. (1990). The essentials of factor analysis: Cassell Educational.

Cohen, J. (1988). Statistical power analysis for the behavioral sciences 2nd edn: Erlbaum Associates, Hillsdale.

Cook, T. D., \& Reichardt, C. S. (1979). Qualitative and quantitative methods in evaluation.

Creswell, J. W. (2013). Research design: Qualitative, quantitative, and mixed methods approaches: Sage publications.

Creswell, J. W., \& Clark, V. L. P. (2011). Designing and conducting mixed methods research.

Cronbach, L. J. (1975). Beyond the two disciplines of scientific psychology. American psychologist, 30(2), 116.

Crotty, M. (1998). The foundations of social research: Meaning and perspective in the research process: Sage.

De Vaus, D., \& de Vaus, D. (2013). Surveys in social research: Routledge.

De Vries, N. J., \& Carlson, J. (2014). Examining the drivers and brand performance implications of customer engagement with brands in the social media environment. Journal of Brand Management, 21(6), 495-515.

Deshpande, R. (1983). " Paradigms Lost": on theory and method in research in marketing. the Journal of Marketing, 101-110.

Easterby-Smith, M., Thorpe, R., \& Lowe, A. (1991). Introduction to Management Research: Sage, London. 